\title{
Does Climatic Variability Influence Agricultural Land Prices under Differing Uses? The Texas High Plains Case
}

\author{
Rachna Tewari $^{1}$, Jeff Johnson ${ }^{2}$, Darren Hudson ${ }^{2}$, Chenggang Wang ${ }^{2}$, Dennis Patterson ${ }^{3}$ \\ ${ }^{1}$ Department of Agriculture, Geosciences, and Natural Resources, The University of Tennessee at Martin, Martin, USA; ${ }^{2}$ Department \\ of Agricultural and Applied Economics, Texas Tech University, Lubbock, USA; ${ }^{3}$ Department of Political Science, Texas Tech Uni- \\ versity, Lubbock, USA. \\ Email: rtewari@utm.edu
}

Received October $7^{\text {th }}, 2013$; revised November $9^{\text {th }}, 2013$; accepted November $30^{\text {th }}, 2013$

Copyright (C) 2013 Rachna Tewari et al. This is an open access article distributed under the Creative Commons Attribution License, which permits unrestricted use, distribution, and reproduction in any medium, provided the original work is properly cited. In accordance of the Creative Commons Attribution License all Copyrights (C) 2013 are reserved for SCIRP and the owner of the intellectual property Rachna Tewari et al. All Copyright (C) 2013 are guarded by law and by SCIRP as a guardian.

\begin{abstract}
The Texas High Plains faces projections of increasing temperature and declining precipitation in the future on account of its semi-arid climate. This research evaluated the impact of climatic variability on agricultural land prices under different land uses in the Texas High Plains, employing the Ricardian approach of land climate pricing over a study period of 1991-2011. The results indicate that climatic variability had a greater impact on irrigated land prices as compared to dryland and ranchland. This study could be instrumental in predictive market analyses of rural land values in semi-arid economies which are vulnerable to future climate change.
\end{abstract}

Keywords: Climatic Variability; Dryland; Irrigated Land; Land Prices; Ranchland; Texas High Plains

\section{Introduction}

The Texas Southern High Plains is a semi-arid region with a strong agricultural economy and is greatly impacted by changes in climatic factors which directly influence the agricultural productivity in the long run. A sizeable proportion of the land in the region is maintained for agricultural and rangeland uses [1]. The productivity of a particular land tract is reflected in land values, which can vary from one tract to another, depending on the fertility, soil type, precipitation, and groundwater availability for irrigation, which in turn affect land quality. In this manner, per unit land values clearly vary between irrigated cropland, dryland and rangeland. The 4th assessment report by the International Panel on Climate Change [2] predicted significant impacts on the agricultural productivity of a transitional area like the Texas High Plains. With projections of increasing temperature and declining precipitation for the region, there will be a definitive impact on the agricultural productivity and land values in the region. This impacts the real estate markets for agricultural land as irrigated land tends to become scarce in the future. The importance of agricultural land itself and changes in agricultural land val- ues for the state of Texas can be attributed to a number of factors. From a countrywide perspective, Texas leads the nation in land area with a total of over 142 million acres devoted to privately-owned farms, ranches and forestlands [1]. These lands provide numerous benefits to the state's population with regard to economic, environmental, and recreational uses and account for about $84 \%$ of the state's entire land area [1]. However, with changes in demographics, rural to urban migration, and changes in the rural agricultural economy, agricultural land tends to become a scarce resource. According to accumulated data from County Appraisal Districts, during a 10-year period from 1997 to 2007, over 2.1 million acres of agricultural land comprising farms, ranches and forestlands were lost to other uses [1]. In 2007, the average appraised market value of farms, ranches and forestlands in Texas was estimated to be $\$ 1196$ per acre and this value represented an increase of about $140 \%$ in appraised market value over the 10-year period. Specifically, the High Plains area had appraised market value increases of about $60 \%$ over the 10-year period [1]. According to the most recent Texas Rural Value Trends report for the year 2012 [3], the preceding drought in the year 2011 caused crop 
failures and diminished yields, which led to a decline in the inventory of good irrigated land in the North Panhandle and the South Plains of Texas. The report also indicates that there continues to be a strong demand throughout the region for most classes of irrigated cropland with even weak or marginal irrigation water. In this manner, any climatic change or abnormality, such as drought, strongly influences the land values in a region, as is evident from the current scenario described above.

\section{Background}

The underlying theory of relating climate variables to the land value is derived from the Ricardian theory which argues that, ceteris paribus, the land with the most suitable climate for the highest valued crop will generate the greatest net revenue (rent) in a region [4]. In this way, potential rents are proportional to the market value of a farm, and land uses are reflected by land value [5]. This clearly indicates that variations in climate will result in varying land use and production, which impacts the profitability and consequently the land values. The sustainability and viability of an agricultural economy, in areas such as the Texas High Plains, depend on the adaptive capabilities of producers in the region to tailor their management and production strategies to climatic and market shocks. As described above, this consequently affects the variations in land use and land values, which becomes all the more apparent given the predictions of bigger shocks in regional climates in the forthcoming time periods. Prior studies in the Texas High Plains that considered the assessment of these changes on land prices from the perspective of climatic variability are limited. Therefore, an economic analysis of the effect of these variations on agricultural land prices under differing uses provides a starting point to develop a framework for land-climate pricing models in the study region using a Ricardian approach. The objective of this study is the quantification of the potential impacts of change in climate on agricultural land values in the Texas High Plains. This study adopts a Ricardian approach to evaluate the impact of climatic variables on the agricultural land values based on land use; specifically irrigated cropland, dryland, and ranchland in the Northern and Southern High Plains of Texas. This is accomplished by developing a seasonal land-climate pricing model to estimate the economic impact of climate and non-climate variables on the agricultural land prices in the Northern and Southern High Plains of Texas for the period 1991-2011, on a quarterly basis.

\section{Prior Work}

This literature review emphasizes the suitability of the Ricardian approach to assess the economic impact of climatic factors on the agricultural land values. We review the available studies related to assessing the economic impact of climatic variability on agricultural land values to establish a foundation for developing the conceptual framework for the current study.

One of the earliest approaches towards the assessment of farm values across different climate zones was suggested by economist David Ricardo, and has been adopted by several researchers to capture climatic effects on farmland productivity and land values. In this approach, long run sensitivity of farm performance to climate is assessed by measuring changes in farm performance. The original method suggested by Ricardo argues that farm productivity and land values in the long run are represented through farmland rents, and therefore farmland values are representative of the present value of future net revenue generated through all activities on the farm. The basic concept in the above approach was initially modified by [4], to study the impacts of climatic, economic, and environmental factors on the value of agricultural lands. This approach is considered a pioneer among many others for estimating climatic effects on agricultural land values. The underlying idea in this study is that land values and agricultural practices are correlated with climate (environmental variables). The Ricardian approach focuses on land rent which is defined as the observed market rent that is equal to the annual net profits from the production of a particular commodity that represents the optimal use of land [4]. As the production of an agricultural commodity is greatly influenced by climatic factors, there is a clear relation between the climatic factors and land values. In this manner, the economic impacts of climatic changes are captured by changes in land values across different conditions. The land climate Ricardian model is an effective measure to conduct an econometric estimation for analyzing the impact of climatic, socioeconomic, and geographical variables on the value of agricultural land. This also assists in estimating the marginal contribution of different attributes to the net farm income as capitalized in land value. The underlying idea again being that with changes in climate, the most profitable use of land will also change. Another important aspect is that climate is considered exogenously in the model, and therefore can effectively capture the impact of climatic changes on agricultural land values [6]. However, this model just like any other method also faces certain limitations. First, the Ricardian model underestimates damages and overestimates benefits through the assumption of constant prices [6]. [7] assert that this assumption is a major limitation of the Ricardian approach and a global agricultural model could provide a solution by incorporating changes and shifts in agricultural commodity prices and input supplies. Another drawback of Ricardian models is the assumption that farmers are ca- 
pable of observing changes that occur in the immediate affecting climate, and will adapt to the climatic changes in a cost-effective manner. However, several studies have concluded that producers adjust their estimate of the true climate at a much slower pace than assumed, resulting in a rather expensive adjustment [8]. In spite of the above limitations, the Ricardian model still provides a fair estimation of the impacts of changes in climatic factors on agricultural land values, and can be applied to different regions. The Ricardian approach for estimating the economic effects of climate change on agriculture has been widely used across various countries and regions includeing United States, Canada, South East Asia, Europe, and South America. The following section of this literature review provides a description of some important studies that will prove useful in developing an understanding of the approach and applying it to the current study.

In their widely acclaimed paper that employed a Ricardian approach for valuing economic impacts of climate [4] set up a cross-sectional analysis which regresses per acre farm values for almost 3000 counties across the United States on different climatic, economic and geophysical variables. The results suggested that higher temperatures in all seasons except autumn led to reduced average farm values, while more precipitation outside of autumn increased farm values. They discovered that a quadratic relationship exists between farm land value and climate variables (normal daily mean temperature and normal precipitation). In terms of monetary impacts, their results indicated that in the United States, farm value impacts range from a loss of $\$ 5.8$ billion to a gain of $\$ 36.6$ billion, depending on the type of model and global warming climate scenarios used. Following their initial approach as mentioned above [9] applied the above method to per acre aggregate farm values on a county basis. They concluded that climate change has a twofold impact which extends to both existing farm values and the likelihood of farming the land or not. Further [7] extended the Ricardian method to incorporate inter-annual temperature and precipitation changes and concluded that the model showed a higher sensitivity to inter-annual temperature variations than the inter-annual precipitation changes. In another interesting study by [10], which was an extension to the previous study by [4], the impact of surface water withdrawal on farm value variations was evaluated. In addition, this study also evaluated the climate sensitivity of agricultural production across the United States. This study concluded that although irrigated cropland values increased with temperature, they were not sensitive to changes in precipitation. The study concluded that expansion of irrigated agriculture could prove beneficial for farmers as an adaptive measure for dealing with climatic changes.

Following the above studies by Mendelsohn and co- authors, several other studies in the last decade studied the impact on climate change by incorporating irrigation changes and other factors on agricultural land values and agricultural profits in the U.S. [11] expanded the above mentioned Ricardian studies to correct for potential bias in the model for inadequate representation of irrigation treatments, and concluded that using more accurate measures to represent climate variables will increase the robustness of the model.The study resulted in concluding an annual loss in profits ranging from $\$ 5$ to $\$ 5.3$ billion for the U.S. counties. In a subsequent study [12] used individual farms data sets to assess the impact of climate and irrigation water availability on farm land value of California. The findings of the study indicate that heating-degree days and irrigation water, both had a significant influence on agricultural land values in California. [13] analyzed the impacts of random variations in temperature and precipitation on U.S. agricultural profits on a year to year basis. The results of the study indicated a 4 percent increase in profitability on an annual basis (amounting to $\$ 1.3$ billion in 2002 dollars), as attributed to climate change. The findings of [13] appear to disagree with the widespread view about the negative welfare impacts of climate change on the U.S. agricultural sector [6].

Similar studies have also been conducted in other parts of the world using the Ricardian approach as the underlying concept to estimate the impacts of climate change on farmland values. [14] used the Ricardian approach to estimate the marginal value of different sets of farmland attributes in England and Wales. The study concluded that climate, soil quality, elevation, as well as structural characteristics of a particular farmland, had significant impacts on the prices of farmlands in the study area. This study also inferred that given the considerable influence of plot size on the average per acre price of land, the owners of farmland in the study region also bear the constraints of their inability to consolidate the land for sale. In a recent study, [6] analyzed the impacts of a set of potential climate change and global change in prices scenarios on the economics of prairie agriculture in $\mathrm{Ca}$ nadian Provinces. This study employed a two way fixed effects panel model with time and provinces group fixed effects to estimate the above effects. The predicted impacts of change in precipitation, temperature increase, and rise in future global market prices indicated that climate change will lead to nonlinear effects on prairie agriculture in Canada. This study specifically showed positive marginal impacts of water related climate variables on agricultural land values. [15] estimated the impact of climate change on South American agriculture considering farmer adaptations. They employed a Ricardian analysis of 2300 farms to estimate the effects of global warming on land values for different countries in the Southern 
Cone region and the Andean region of South America. In order to predict climate change impacts for this century, they examined severe, less severe, and mild climate change scenarios as predicted by three Atmospheric Oceanic General Circulation Models. Under predictions for all the three scenarios, farmland values decrease with increasing levels of severity with increase in both temperature and rainfall with the exception of irrigated farms. The decline in farmland values becomes higher with increasing levels of severity. The study also concluded that small farms are more vulnerable to increasing temperatures, while large farms are more vulnerable to precipitation increase. [16] studied the impact of change in climate normals on the agricultural sector in Pakistan. They employed a cross sectional Ricardian model for eleven districts in Punjab region of Pakistan to assess the impacts of climate change on agricultural land values by including two major seasonal variables, namely Kharif (rainy season) and Rabi (winter season). These two variables are crucial to the agricultural sector in the study region, as they represent seasons in the context of sowing and harvesting time periods. The results of the study inferred that mean precipitation and mean minimum Kharif temperatures show a significant positive relationship with land prices, while mean maximum Kharif temperature showed no statistical significance with land prices. On the other hand, precipitation and mean minimum temperature in Rabi season showed a significant negative relationship with land prices, while mean maximum Rabi temperature showed a significant positive relationship with land prices. Further, [6] has suggested that the land climate price model can be used to estimate the impact of climatic, socio-economic, and geographical variables in valuing agricultural land which allows measuring of the marginal contribution of the attributes in order to capitalize the land value.

\section{Data and Methods}

This study specifically evaluates impacts of variations in weather and climate on agricultural land prices in two major agricultural production areas of the Texas High Plains: 1) Northern High Plains, and 2) Southern High Plains. The study area is presented in Figure 1.

Most studies measuring the economic impact of climatic factors on agricultural sectors have used spatial price models across different locations that relate to a single year, as the availability of time series data on sales or rental prices for different types of agricultural lands is limited. However, this study uses continuous time series data available on a quarterly basis for different land uses in the Texas High Plains, which is an addition to existing literature pertaining to land climate economic analyses in the study area. The land values under differing land uses are procured for the 1st and 2nd districts from the Agricultural Survey data of the Eleventh Federal Reserve

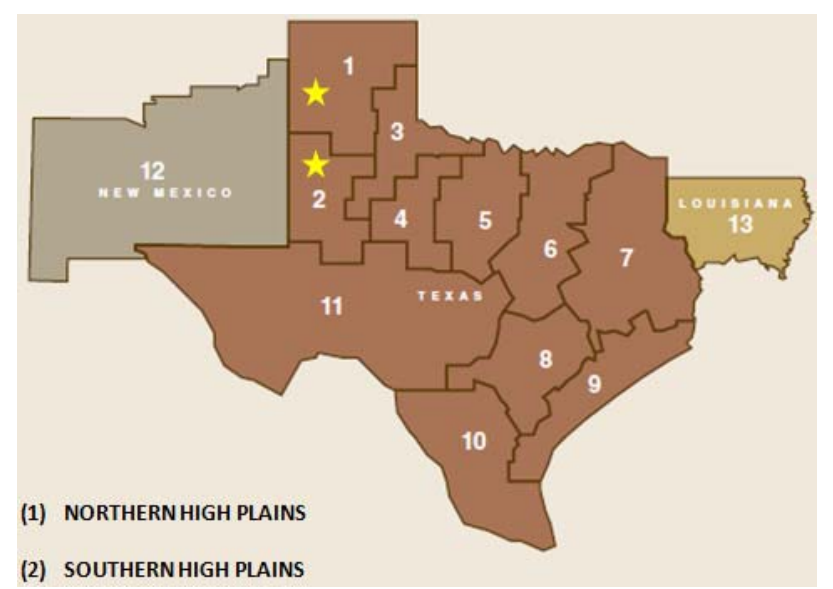

Figure1. Study area-Northern and Southern High Plains Districts from the Agricultural Survey of Federal Reserve bank of Dallas [19].

District, which represent the Northern and Southern High Plains of Texas, respectively (Figures 2 and $\mathbf{3}$ ).

The independent variables are categorized into two groups of climate and non-climate variables. The dependent variable in the study is the quarterly average sale price per acre (\$/acre) of agricultural land in a particular district, which is deemed to be consistent with the Ricardian approach based on land climate pricing. Climate variables used in the study are daily observations averaged to form quarterly mean observations from 1991 to 2011 in order to create homogeneity in the analysis with the dependent variables time series distribution and also to avoid losing degrees of freedom. Means of minimum and maximum temperature are measured in degree Celsius $\left({ }^{\circ} \mathrm{C}\right)$, while mean of precipitation is measured in millimeters. The source of this data is the GHCN daily data (Global Historical Climatology Network) for individual weather stations from the National Climate Data Center of the National Oceanic and Atmospheric Administration [17]. These data are obtained for $2-3$ weather stations in each district and observations are averaged to represent the local climate for each district. For non-climate variables, population density (persons per square mile) [18], total personal income per capita [18], and the Texas Business Cycle Index are used. The Texas Business Cycle Index is an economic statistic to assess the current state of the economy in the State of Texas $(1987=100)$, and is constructed using payroll employment, gross state product, and the unemployment rate [19]. All nominal variables in the model are deflated by the Consumer Price Index for Texas $(1982-84=100)$. The source of data and notations for the dependent and independent variables in the study are defined in Table $\mathbf{1}$.

\section{Econometric Model}

The standard model based on studies by $[6,16]$ is given 


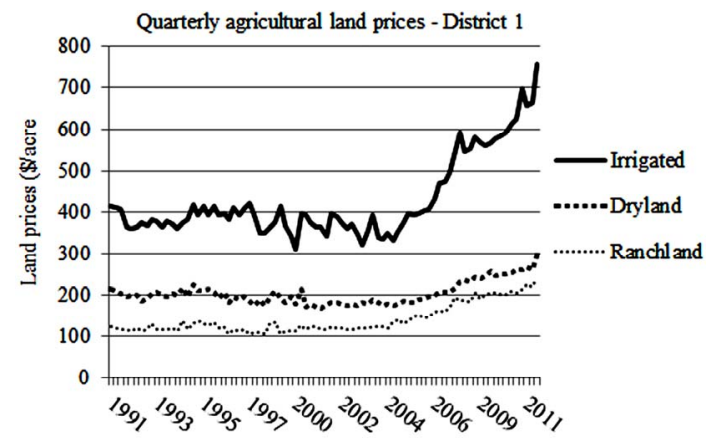

Figure 2. Agricultural land prices for District 1.

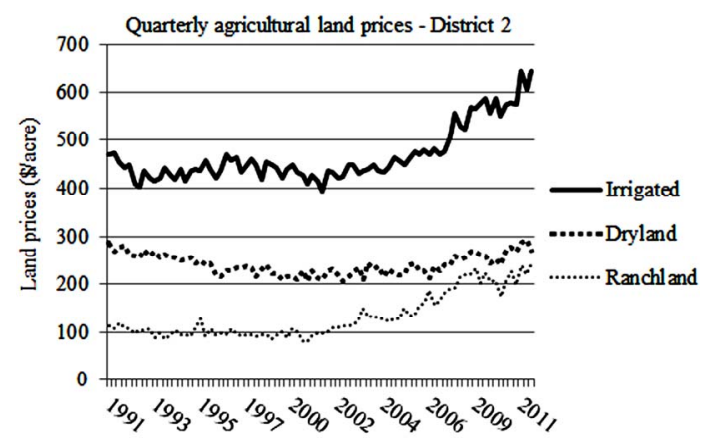

Figure 3. Agricultural land prices for District 2.

Table 1. Description and sources of variables employed to estimate the model.

\begin{tabular}{ccc}
\hline Variable & Notation & Source of Data \\
\hline DEPENDENT VARIABLES & & \\
Irrigated Land Price & IRRLP $^{*}$ & ${ }^{*}$ Quarterly \\
Dryland Price & DRLP $^{*}$ & Ag. Survey \\
Ranchland Price & RANLP $^{*}$ & {$[19]$} \\
INDEPENDENT VARIABLES & & \\
Non Climate Variables & & \\
Population Density (per sq. mile) & POPDEN & {$[18]$} \\
Total Personal Income (per capita) & PIC & {$[18]$} \\
Texas Business Cycle Index & Bindex & {$[19]$} \\
Climate Variables & & \\
Maximum Temperature $\left({ }^{\circ} \mathrm{C}\right)$ & TMAX & {$[17]$} \\
Minimum Temperature $\left({ }^{\circ} \mathrm{C}\right)$ & TMIN & {$[17]$} \\
Precipitation $(\mathrm{mm})$ & PRCP & {$[17]$} \\
\hline
\end{tabular}

by:

$$
Y_{i t}=\alpha_{0}+\beta C_{i t}+\beta_{2} C^{2} i t+\beta_{3} Z_{i t}+e_{i t}
$$

In this specification, $Y_{i t}=$ per acre agricultural land price in $i^{\text {th }}$ district over time period $t ; \alpha_{0}=$ constant; $C_{i t}=$ vector of climate variables in $i^{\text {th }}$ district for time period $\mathrm{t}$; $Z_{i t}=$ vector of non-climate variables in $i^{\text {th }}$ district for time period t; $e_{i t}=$ stochastic error term.

Feasible Generalized Least Square (FGLS) technique is used to estimate the regression model. The econometric model specification involves regressing per acre farm- land value against climate variables and socioeconomic variables (considered exogenous). The significance level of each explanatory variable in the Feasible GLS model is determined by the coefficient t-statistics. Individual explanatory variable's direction of influence on the dependent variable is also checked. Based upon the methodology, the land climate pricing model estimates the economic impact of climate normals for 2 districts in Texas over a 21-year period (1991-2011) for three specific land uses: irrigated land, dryland, and ranchland. The data observations are gathered on a quarterly basis and a total of 84 observations over time are available for each variable for each district.

\section{Results}

Throughout the period of study, quarterly prices of irrigated land stayed the highest, followed by dryland and ranchland respectively, among the three land use types in District 1 (Figure 2). The dryland and ranchland prices showed an almost stable trend until the late 1990s and early 2000s, with a slight upward trend following year 2005 onwards. On the other hand, irrigated land prices showed a higher degree of fluctuation when compared to the other twoland use prices, with a very strong upward trend from year 2005 onwards.

A similar trend in agricultural land prices was observed during the study period for District 2. Quarterly prices of irrigated land continuously stayed the highest, followed by dryland and ranchland respectively, as was the case in District 1 . The starting gap between the dryland and ranchland prices, which was much higher during the early 90's, narrowed over time in District 2 (Figure 3). Again, the year 2005 saw a similar upward trend in the land prices for the three land use types, with the trend being stronger for both irrigated land and ranchland, when compared to dryland. The report on trends in rural land values for Texas for the year [20] explains these patterns for the different land use prices of rural agricultural land. According to the report, the agricultural land market in the year 2005 witnessed increasing pressure from the hunting and recreational property buyers, which led to increased ranchland prices and hunting lease rates due to a strong recreational demand in both districts. The report also brought to light an important observation with regard to climatic influences on agricultural land purchases. It was suggested that a favorable ecological climate proved to be a positive influence on the movement of numerous dairies into the North Panhandle and the South Plains further increasing land purchase, and adding employment opportunities in the area. The demand for dryland farms also showed a slightly increasing trend on account of increased production costs, and it was observed that the dryland producers in the region always preferred to lease on a crop share basis. Table 2 provides 
Table 2. Descriptive statistics of variables employed.

\begin{tabular}{cccccc}
\hline Variable & $\mathrm{N}$ & Mean & StdDev & Min & Max \\
\hline Year & 168 & 42.5 & 24.3 & 1.0 & 84.0 \\
Quarter & 168 & 2.5 & 1.1 & 1.0 & 4.0 \\
District & 168 & 1.5 & 0.5 & 1.0 & 2.0 \\
IRRLP $(\$ /$ acre $)$ & 168 & 449.0 & 82.5 & 313.8 & 758.9 \\
DRLP $(\$ /$ acre $)$ & 168 & 223.5 & 30.4 & 168.8 & 298.4 \\
RANLP $(\$ /$ acre $)$ & 168 & 137.3 & 41.5 & 80.6 & 246.3 \\
TMAX $\left({ }^{\circ} \mathrm{C}\right)$ & 168 & 23.2 & 8.5 & 7.6 & 76.8 \\
TMIN $\left({ }^{\circ} \mathrm{C}\right)$ & 168 & 8.0 & 8.8 & -5.6 & 62.2 \\
PRCP $(\mathrm{mm})$ & 168 & 47.8 & 92.0 & 0.001 & 371.7 \\
POPDEN & 168 & 196.2 & 83.1 & 98.0 & 315.0 \\
$($ per sq. mile) & & & & & \\
PIC & 168 & 15,306 & 1,228 & 13,030 & 18,159 \\
$(\$$ per capita $)$ & & 155.0 & 23.1 & 113.3 & 187.7 \\
Bindex & 168 & 155.0
\end{tabular}

the descriptive statistics of variables employed to estimate the model.

There were a total of 168 observations for each variable, with each observation indicating a value for a representative quarter in each year. Given that the data set included time series observations on a quarterly basis, the model data were first checked for the presence of autocorrelation among residuals using the Durbin Watson (DW) statistic. The regression model for the three land use prices (irrigated, dryland, and ranchland), showed statistically significant results for the DW test, and therefore the data were transformed to first difference values using the first difference estimator, and were again subject to the DW test to further check for the presence of autocorrelation. The DW statistics now showed no autocorrelation, and indicated the suitability of the transformed values for further analysis. Including a lag term for the dependent variable in the model also showed significant autocorrelation using the Durbin $h$ test, and therefore the lag terms were not included in the model.

This study further evaluated the data using the FGLS approach for seemingly unrelated regression, and some interesting patterns are noticed. For each land use type, an individual equation is used allowing for a seemingly unrelated regression procedure. The lag prices of the dependent variable are not included on account of significant autocorrelation, as indicated earlier. The results of this set of equations showed varied results for different land use types. As suggested in the land climate pricing model, the quadratic terms for the climate variables were also included in the model. The system weighted $\mathrm{R}^{2} \mathrm{ob}-$ tained for this model was 0.3437 , and the results for the regressions for irrigated land, dryland, and ranchland are provided in Tables 3-5 respectively.

For the irrigated land prices, all the climatic variables except precipitation showed statistically significant results. The estimates for the maximum and minimum av-
Table 3. Results of Feasible GLS for irrigated land prices.

\begin{tabular}{cccc}
\hline \multicolumn{3}{c}{ Irrigated land prices } \\
\hline Variable & Parameter & $t$ Value & $\operatorname{Pr}>|t|$ \\
\hline Intercept & -0.1364 & -0.04 & 0.9679 \\
TMAX & -2.3787 & -1.83 & $0.0694^{* * *}$ \\
(TMAX)2 & 0.0210 & 0.34 & 0.7361 \\
TMIN & 2.2122 & 1.71 & $0.0895^{* * *}$ \\
(TMIN)2 & -0.0203 & -0.35 & 0.7245 \\
PRCP & -0.0181 & -0.97 & 0.3336 \\
(PRCP)2 & 0.0000 & 0.48 & 0.6326 \\
PIC & 0.0051 & 1.41 & 0.1606 \\
POPDEN & -0.3760 & -0.36 & 0.7179 \\
Bindex & 3.2331 & 2.06 & $0.0413^{* *}$ \\
\hline
\end{tabular}

Table 4. Results of Feasible GLS for dryland prices.

\begin{tabular}{cccc}
\hline \multicolumn{3}{c}{ Dryland prices } \\
\hline Variable & Parameter & $t$ Value & $\operatorname{Pr}>|t|$ \\
\hline Intercept & -1.0624 & -0.62 & 0.5356 \\
TMAX & 0.1084 & 0.16 & 0.8694 \\
(TMAX)2 & 0.0252 & 0.80 & 0.4243 \\
TMIN & -0.2311 & -0.35 & 0.7247 \\
(TMIN)2 & -0.0205 & -0.70 & 0.4830 \\
PRCP & 0.0050 & 0.54 & 0.5929 \\
(PRCP)2 & 0.0000 & 1.15 & 0.2538 \\
PIC & 0.0031 & 1.68 & $0.0950^{* * *}$ \\
POPDEN & 0.0439 & 0.08 & 0.9335 \\
Bindex & 0.1934 & 0.24 & 0.8082
\end{tabular}

Table 5. Results of Feasible GLS for dryland prices.

\begin{tabular}{cccc}
\hline \multicolumn{3}{c}{ Ranchland prices } \\
\hline Variable & Parameter & T Value & $\operatorname{Pr}>|t|$ \\
\hline Intercept & 1.73186 & 1.01 & 0.3122 \\
TMAX & -0.64533 & -0.98 & 0.3275 \\
(TMAX)2 & 0.02634 & 0.84 & 0.4028 \\
TMIN & 0.43984 & 0.67 & 0.5021 \\
(TMIN)2 & -0.02626 & -0.90 & 0.3680 \\
PRCP & 0.01713 & 1.82 & $0.0703^{* * *}$ \\
(PRCP)2 & 0.00001 & 0.27 & 0.7889 \\
PIC & 0.00013 & 0.07 & 0.9424 \\
POPDEN & -0.82555 & -1.57 & 0.1177 \\
Bindex & 0.44500 & 0.56 & 0.5759 \\
\hline
\end{tabular}

${ }^{*}$ denotes $1 \%,{ }^{* *} 5 \%$, and ${ }^{* * *} 10 \%$ level of significance respectively.

erage seasonal temperatures showed a significant negative and positive relation respectively, with the quarterly land prices at the $10 \%$ significance level. The Texas Business Cycle Index, as a measure of current state of the economy again showed a positive significant relation with the irrigated land prices at a 5\% level. All other variables showed no statistically significant relation with 
the irrigated land prices on a quarterly basis.

Evaluating the results for the dryland prices, it was found that while none of the climatic variables showed any statistical significance, the per capita income showed a positive significant relation with the dryland prices at the $10 \%$ level. An interesting result was noted for the ranchland prices, which showed a positive significant relation only with the average seasonal precipitation (at the $10 \%$ level) among all climate and non-climate variables, indicating an increase in ranchland prices which could be accounted for by enhanced productivity due to higher precipitation.

\section{Discussion and Conclusions}

This study evaluated the impact of climatic and socioeconomic variables on quarterly agricultural land prices under different land uses in the Northern and Southern High Plains of Texas, basing itself on the Ricardian approach of land climate pricing. This analysis brings to light the influence of climatic factors on differing land use prices, which stems from the fact that agricultural practices and land use patterns are correlated with the weather and climatic variables, and the agricultural production of a particular commodity that represents the optimal use of land impacts the observed market rent on the land. In this manner, the economic impacts of climatic changes in an area are captured by changes in land values across different conditions, which are the focal point of this research. The results indicated that irrigated land prices showed significance with a larger number of explanatory variables, specifically climatic, when compared to dryland and ranchland with the latter showing significance only with regard to precipitation. This indicates a stronger impact of climatic factors on the productivity of irrigated land thereby strongly impacting the land prices, when compared to dryland and ranchland. Further, the irrigated land prices showed significance with regard to the business index, while dryland prices showed significance with regard to per capita income among the different socioeconomic variables. Ranchland prices did not show any significant effects for any socioeconomic variables.

This study faced certain limitations especially with regard to data availability for socioeconomic factors on a quarterly basis and it will be useful to include other socio-economic characteristics of the region as well, and a higher number of cross-sectional units to enhance the performance and fit of the land climate model used. The latter will also allow for including a one-way panel fixed effects model with a higher number of spatial units. The results of the study provide an initial insight into the application of climatic data for understanding changes in agricultural land prices under varying land uses. For a semi-arid region with a strong agricultural economy like the Texas High Plains, prices for varying land uses as impacted by future climate could exert significant impacts on land management policies in the region. This study could provide a framework for developing predictive market analyses of rural land values in the region, which faces projections of increasing temperature and declining precipitation thereby influencing agricultural production in the future on account of its semi-arid climate.

\section{Acknowledgements}

This research was supported in part by the Ogallala Aquifer Program, a consortium between the USDA Agricultural Research Service, Kansas State University, Texas AgriLife Research, Texas AgriLife Extension Service, Texas Tech University, and West Texas A \& M University. The authors would also like to thank the Federal Reserve Bank of Dallas for their contribution to the data sources.

\section{REFERENCES}

[1] Texas A \& M Institute of Renewable Natural Resources, "Texas Land Trends," 2012. http://texaslandtrends.org/Briefings/Landuse.aspx.

[2] IPCC (Intergovernmental Panel on Climate Change), "Climate Change 2007: Synthesis Report”, 2007.

http://www.ipcc.ch/publications_and_data/ar4/syr/en/spm s3.html

[3] Real Estate Center at Texas A \& M University, "Texas Rural Value Trends," 2012.

http://recenter.tamu.edu/data/rland/trends/ASFMRA_201 1.pdf.

[4] R. Mendelsohn, W. D. Nordhaus and D. Shaw, "The Impact of Global Warming on Agriculture: A Ricardian Analysis," American Economic Review, Vol. 84, No. 4, 1994, pp.753-771.

[5] J. Currie, "The Economic Theory of Agricultural Land Tenure," Cambridge University Press, Cambridge, 1981.

[6] A. Amiraslany, "The Impact of Climate Change on Canadian Agriculture: A Ricardian Approach," Unpublished Thesis, University of Saskatchewan, Saskatoon, 2010. http://library2.usask.ca/theses/available/etd-05252010-10 2012/

[7] R. Mendelsohn and W. D. Nordhaus, "The Impact of Global Warming on Agriculture: A Ricardian Analysis: Reply," American Economic Review, Vol. 89, No. 4, 1999, pp. 1049-1052. http://dx.doi.org/10.1257/aer.89.4.1049

[8] J. Quiggin and J. K. Horowitz, "The Impact of Global Warming on Agriculture: A Ricardian Analysis: Comment," American Economic Review, Vol. 89, No. 4, 1999, pp. 1044-1045. http://dx.doi.org/10.1257/aer.89.4.1044

[9] R. Mendelsohn, W. D. Nordhaus and D. Shaw, "Climate Impacts on Aggregate Farm Value: Accounting for Adaptation," Journal of Agricultural and Forest Meteorol- 
ogy, Vol. 80, 1996. pp. 55-66. http://dx.doi.org/10.1016/0168-1923(95)02316-X

[10] Mendelsohn, R. and A. Dinar, "Climate, water, and agriculture," Land Economics, Vol. 79, No. 3, 2003, pp. 328341. http://dx.doi.org/10.2307/3147020

[11] W. Schlenker, W. Hanemann and A. Fisher, "Will U.S. Agriculture Really Benefit from Global Warming? Accounting for Irrigation in the Hedonic Approach," The American Economic Review, Vol. 95, No. 1, 2005, pp. 395-406. http://dx.doi.org/10.1257/0002828053828455

[12] W. Schlenker, W. Hanemann and A. Fisher, "Water Availability, Degree Days, and the Potential Impact of Climate Change on Irrigated Agriculture in California," Climatic Change, Vol. 81, No. 1, 2007, pp. 19-38. http://dx.doi.org/10.1007/s10584-005-9008-z

[13] O. Deschens and M. Greenstone, "The Economic Impacts of Climate Change: Evidence from Agricultural Profits and Random Fluctuations in Weather," American Economic Review, Vol. 97, No.1, 2007, pp. 354-385. http://dx.doi.org/10.1257/aer.97.1.354

[14] D. Maddison, "A Hedonic Analysis of Agricultural Land Prices in England and Wales," European Review of Agri- cultural Economics, Vol. 27, No. 4, 2000, pp. 519-532.

[15] S. N. Seo and R. Mendelsohn, "An Analysis of Crop Choice: Adapting to Climate Change in South American Farms," Ecological Economics, Vol. 67, No. 1, 2008, pp. 109-116. http://dx.doi.org/10.1016/j.ecolecon.2007.12.007

[16] U. Hanif, S. H. Syed, R. Ahmad and K. M. Malik, "Economic Impact of Climate Change on the Agricultural Sector of Punjab," The Pakistan Development Review, Vol. 49. No. 4, 2010, pp. 771-798.

[17] National Oceanic and Atmospheric Administration, "National Climatic Data Center," 2012.

[18] U.S. Census Bureau, 2012. http://www.census.gov/.

[19] Federal Reserve Bank of Dallas, "Agricultural Survey," 2012. http://www.dallasfed.org/research/agsurvey/index.cfm.

[20] Real Estate Center at Texas A\&M University, 2005. http://recenter.tamu.edu/data/rland/trends/ASFMRA05.pd f 